\title{
Chromium in Fermented Rice Flour with Bakery's Yeast
}

\author{
Rudiana Agustini*, Filla Qodaria N., I Gusti Made Sanjaya \\ Department of Chemistry \\ Universitas Negeri Surabaya \\ Surabaya, Indonesia \\ rusdianaagustini@unesa.ac.id
}

\begin{abstract}
Research is conducted to determine the chromium content in rice flour which is fermented with bakery's yeast. The procedure involves several steps including sample preparation, fermentation, making crude bromelain enzymes, making YHE (Yeast Hydrolysate Enzymatic), and determining the chromium content. In this study, measurements were taken on several parameters which included measurement of chromium (III) and chromium (VI) measured by a voltammeter instrument. The results showed that Yeast - black rice had the highest chromium (III) content of $112 \times 10^{-4} \%$. Likewise, the chromium (VI) content from YHE - black rice was also the highest compared to YHE - white rice and YHE - red rice, which amounted to 53 $\mathrm{x} 10^{-4} \%$.
\end{abstract}

Keywords-YHE (Yeast Hydrolysate

Enzimatic), chromium, bakery's yeast

\section{INTRODUCTION}

Chromium is a type of body mineral that is used in small amounts to maintain normal body functions. It is needed by our body in the metabolism of fats and carbohydrates [1] [2]. Chromium is suspected in the body can affect the behavior of the hormone insulin, a hormone that plays a role in regulating blood sugar levels.

Chromium is found widely in environments such as air, water, soil, plants and animals. Chromium can be obtained by consuming several types of food. Foods that contain chromium are grain breads, cereals, lean meats, organ meats, cheeses, mushrooms, asparagus, green beans, potatoes, prunes, bananas and nuts.

Chromium has several functions and benefits, one of which is to help metabolize carbohydrates. In addition, this type of mineral also functions to monitor blood sugar levels and help stabilize blood sugar. Chromium mineral sources that are quite good are found in Saccharomyces cerevisiae, a microorganism classified as khamir. This khamir is one of them found in bakery's yeast or also called bread yeast.

Saccharomyces cerevisiae includes khamir from the Ascomycetes class which contains lots of protein, carbohydrates and fats, so that it can be consumed by humans and animals to supplement their daily nutritional needs. Saccharomyces cerevisiae is very easily grown on a variety of media provided there are sources of carbon, nitrogen, hydrogen, oxygen, sulfur, calcium, vitamins, minerals and water [3] [4]. The growth of Saccharomyces cerevisiae can be influenced by several factors, one of which is fermentation media. The media used must be able to meet the requirements of containing simple carbohydrates. One of the fermentation media that can be used for Saccharomyces cerevisiae is flour which contains mainly starch [5], such as rice and wheat. Some types of rice that are generally available are brown rice, black rice and white rice.

Saccharomyces cerevisiae which is successfully grown can be further processed, which is extracted through an enzymatic hydrolysis process to produce a product known as YHE (Yeast Hydrolisate Enzimatic). Yeast extract is used in the food industry as a flavoring agent for soups, snacks, substitutes for MSG (Monosodium Glutamate), canned foods, plant nutrients, and supplements in health foods. In health food supplements, the content used is chromium. Chromium content in yeast in $1 \mathrm{oz}$ (28.35 grams) is $3.3 \mu \mathrm{g}$ [6].

This study is conducted to determine the chromium content in rice flour fermented with bakery's yeast and then enzymatically hydrolyzed to produce YHE (yeast hydrolysate enzymatic).

\section{RESEARCH MATERIALS AND PROCEDURES}

\section{A. Sample Preparation}

Flour as a fermentation medium such as red, white and black rice flour is dried and mashed or blended. Flour is then filtered by passing the 100 mesh sieve.

\section{B. Fermentation Stage}

As many as 25 grams (in dry weight) of each black, red, and white rice flours are included in different fermenters. Each rice flours is added with $250 \mathrm{ml}$ of boiling distilled water and stirred until the gel is formed. Combine 5 grams of amylase and beta glucoamylase enzymes. The mixture was incubated for 48 hours at $37^{\circ} \mathrm{C}$. The incubated mixture is then added 10 grams of bread yeast and anaerobically fermented for 36 hours at room temperature.

\section{Stage of Making Crude Bromelain Enzyme}

Ten green pineapples were prepared with the pineapple's eye removed, then cut and mashed until smooth with a blender and added with a little distilled water. The crushed pineapple is filtered with a clean cloth. The filtered pineapple results are centrifuged $1500 \mathrm{rpm}$ for 10 minutes. The resulting filtrate was added with $35-40 \%$ ammonium sulfate and stirred slowly using a magnetic stirrer in cold conditions 
for 45 minutes and allowed to stand for 24 hours in the refrigerator. The mixture was centrifuged at a speed of 6000 rpm for 25 minutes to take the supernatant.

\section{Stage of Making YHE}

The fermentation results were carried out by plasmolysis stage by adding $35 \% \mathrm{NaCl}$ for 48 hours. The mixture is then centrifuged at a speed of $1500 \mathrm{rpm}$ for 10 minutes. Yeast fermented from a variety of rice flour produced in the form of pellets is then collected as a fermented solid paste. Fermented solid paste is then added $50 \mathrm{ml}$ of pineapple crude and enzymatic hydrolyzed for 48 hours at temperature $30^{\circ} \mathrm{C}$.

\section{E. Determination of Chromium (III) and Chromium (VI) Content}

Preparation of standard chromium solution was carried out by weighing 0.512481 grams of $\mathrm{CrCl}_{3} .6 \mathrm{H}_{2} \mathrm{O}$ for $\mathrm{Cr}^{3+}$ and 0.283 grams of $\mathrm{K}_{2} \mathrm{Cr}_{2} \mathrm{O}_{7}$ for $\mathrm{Cr}^{6+}$, then each dissolved in $1000 \mathrm{~mL}$ of distilled water to produce each $1000 \mathrm{ppm}$ concentration of mother liquor. Each one hundred milliliters of the two mother liquor solutions were taken and then each diluted with distilled water at a concentration of 5,10,20,40, and $80 \mathrm{ppm}$. Sample preparation was carried out by weighing each of five grams of sample, namely YHE from red rice flour, white rice flour, and black rice flour and then each of them was put into a dry porcelain crust and the weight was already known. The samples are then put into a furnace at a temperature of $500^{\circ} \mathrm{C}$ for 4 hours. Each porcelain crust was taken and weighed the end result. Each porcelain crust was dissolved using $1 \mathrm{~mL}$ concentrated $\mathrm{HCl}$ and $1 \mathrm{~mL}$ concentrated $\mathrm{HNO}_{3}$. The mixture was allowed to stand for 24 hours. Each porcelain crucible was dissolved with aquademin to a volume of $25 \mathrm{~mL}$ and then taken $10 \mathrm{~mL}$ of sample in each dissolved porcelain crucible, and added $5 \mathrm{~mL}$ of citrate buffer $\mathrm{pH} 3$ for $\mathrm{Cr}^{3+}$, and citrate buffer $\mathrm{pH} 4$ for $\mathrm{Cr}^{6+}$ and also added $10 \mathrm{~mL} 0.1 \mathrm{~N} \mathrm{KCl}$. Each sample was tested for its chromium content using a voltammetry instrument. The obtained voltammogram is then analyzed using the origin pro7.0 application to determine the levels of $\mathrm{Cr}^{3+}$ and $\mathrm{Cr}^{6+}$.

\section{RESULT AND DISCUSSION}

\section{A. Determination of Chromium (III)}

Table I shows the results of current strength measurements for standard $\mathrm{Cr}$ (III) solutions of various concentrations.

TABLE I. CR (III) STANDARD SOLUTION VOLTAMMOGRAM

\begin{tabular}{|c|c|}
\hline Concentration $(\%)$ & $\operatorname{Ipc}(\mathrm{A})$ \\
\hline $5 \times 10^{-4}$ & $3.386295 \mathrm{E} 8$ \\
\hline $1 \times 10^{-3}$ & $3.412831 \mathrm{E} 8$ \\
\hline $2 \times 10^{-3}$ & $3.4521 \mathrm{E} 8$ \\
\hline $4 \times 10^{-3}$ & $3.57035 \mathrm{E} 8$ \\
\hline $8 \times 10^{-3}$ & $3.711003 \mathrm{E} 8$ \\
\hline
\end{tabular}

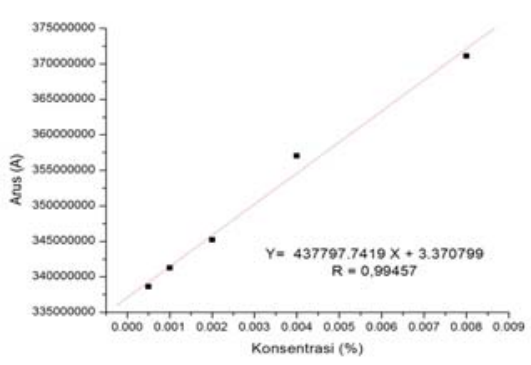

Fig 1. Cr (III) Standard Solution Calibration Curve

The results of concentration mapping on the current strength of the standard solution Cr (III) produces the line equation $\mathrm{Y}=437797,7922 \mathrm{x}+3,370798$. Substituting the results of current strength measurements from each sample of white rice, brown rice, black rice, white rice yeast (yeast$\mathrm{BP})$, red rice yeast (yeast-BM), black rice yeast (yeast-BH), YHE white rice ( YHE-BP), YHE red rice (YHE-BM), and YHE black rice (YHE-BH) into equation $\mathrm{Y}=437797,7922$ $\mathrm{x}+3,370798$ it can produce $\mathrm{Cr}$ (III) concentration from each of these ingredients. Table 2 shows the results of the measurement of $\mathrm{Cr}$ (III) of each ingredient, namely. white rice, brown rice, black rice, white rice yeast, red rice yeast, black rice yeast, white rice YHE, red rice YHE, and black rice YHE.

Table II shows that $\mathrm{Cr}$ (III) content increased in white rice yeast, red rice yeast, and black rice yeast after fermentation with an increase of $81 \%, 18 \%$, and $92 \%$, respectively. This increase is likely due to the addition of bakery's yeast. The increase in Chrom (III) content also occurred in white rice YHE, red rice YHE, and black rice YHE compared to white rice, brown rice and white rice with a consecutive increase of $12 \%, 18 \%$, and $20 \%$. The results of this study also showed that after the yeast enzymatic hydrolysis process into YHE there was a decrease in $\mathrm{Cr}$ (III) content in white rice YHE, brown rice YHE, and black rice YHE respectively $69 \%, 66 \%$, and $72 \%$. This is likely one of the causes is that there is $\mathrm{Cr}$ (III) which is released during the centrifuge.

TABLE II. RESUlts OF CR (III) MEASUREMENT

\begin{tabular}{|c|c|c|c|}
\hline Sample & $\begin{array}{c}\mathrm{Cr}(\mathrm{III}) \\
\text { content } \\
(\%)\end{array}$ & $\begin{array}{c}\text { Increase of } \\
\% \mathrm{Cr} \text { (III) } \\
\text { (from flour to } \\
\text { yeast) }\end{array}$ & $\begin{array}{l}\text { Decrease of } \\
\% \mathrm{Cr} \text { (III) } \\
\text { (from yeast } \\
\text { to YHE) }\end{array}$ \\
\hline white rice & $20 \times 10^{-4}$ & & \\
\hline red rice & $19 \times 10^{-4}$ & & \\
\hline black rice & $20 \times 10^{-4}$ & & \\
\hline yeast-white rice & $101 \times 10^{-4}$ & 81 & \\
\hline yeast-red rice & $103 \times 10^{-4}$ & 84 & \\
\hline yeast-black rice & $112 \times 10^{-4}$ & 92 & \\
\hline YHE-white rice & $32 \times 10^{-4}$ & 12 & 69 \\
\hline YHE-red rice & $37 \times 10^{-4}$ & 18 & 66 \\
\hline YHE-black rice & $40 \times 10^{-4}$ & 20 & 72 \\
\hline
\end{tabular}




\section{B. Determination of Chromium (VI)}

Table 3 shows the results of the standard curve voltammogram obtained from the current with respect to concentration.

TABLE III. RESUlts OF CR (III) MEASUREMENT

\begin{tabular}{|c|c|}
\hline Concentration (\%) & Ipc (A) \\
\hline $5 \times 10^{-4}$ & $3.179479 \mathrm{E} 8$ \\
\hline $1 \times 10^{-3}$ & $3.206797 \mathrm{E} 8$ \\
\hline $2 \times 10^{-3}$ & $3.319159 \mathrm{E} 8$ \\
\hline $4 \times 10^{-3}$ & $3.513842 \mathrm{E} 8$ \\
\hline $8 \times 10^{-3}$ & $3.817654 \mathrm{E} 8$ \\
\hline
\end{tabular}

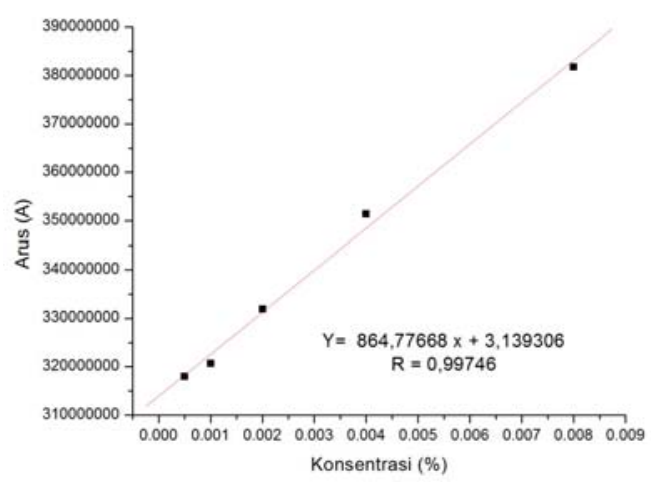

Fig 2. Cr (VI) Standard Solution Calibration Curve

Mapping of the concentration on the current strength of the standard solution $\mathrm{Cr}$ (VI) produces the line equation $\mathrm{Y}=$ $864,77668 x+3,139305$. Substituting the results of current strength measurements from each sample of white rice, brown rice, black rice, white rice yeast, red rice yeast, black rice yeast, white rice YHE, red rice YHE, and black rice YHE into the equation $\mathrm{Y}=864,77668 \mathrm{x}+3,139305$, the concentration of $\mathrm{Cr}$ (VI) from the material can be known. Table 4 shows the results of measurements of $\mathrm{Cr}$ (VI) from each ingredient of white rice, brown rice, black rice, white rice yeast, red rice yeast, black rice yeast, YHE white rice, YHE brown rice, and YHE black rice.

bakery's yeast. Bakery yeast is known to be rich in chromium. The increase also occurred in YHE white rice, YHE red rice, and YHE black rice compared to white rice, brown rice and black rice with a $6 \%, 8 \%$ and $10 \%$ increase respectively. The results also showed that after the enzymatic yeast hydrolysis process to YHE there was a decrease in the content of $\mathrm{Cr}$ (VI) in YHE - white rice, YHE- red rice, and YHE - black rice with a decrease of $34 \%, 32 \%$ and $34 \%$ respectively. This may be one of the causes is that there is $\mathrm{cr}^{6+}$ which is released when the centrifuge.

In YHE-black rice, $\mathrm{Cr}$ (VI) content decreased from $53 \mathrm{x}$ $10^{-4} \%$ to $19 \times 10^{-4} \%$. In YHE-black rice, $\mathrm{Cr}$ (VI) content decreased from $49 \times 10^{-4} \%$ to $17 \times 10^{-4} \%$. Whereas in YHE-white rice, the content of Cr (VI) decreased from $48 \mathrm{x}$ $10^{-40} \%$ to $15 \times 10^{-4 \%} \%$. This indicates that yeast - red rice and yeast - black rice has the ability to bind Cr (VI) greater than yeast - white rice.

\section{CONCLUSION}

Based on the data analysis, it can be concluded that the highest chromium (III) content are yeast - black rice products at $112 \times 10^{-4} \%$. The highest chromium (VI) content is yeast - black rice products by $53 \times 10^{-4 \%}$.

\section{REFERENCES}

[1] W. Mertz. 1993. "Chromium in human nutrition: a review". J. Nutr, 1993, 123:626-633.

[2] R.A. Anderson, "Chromium, glucose tolerance, diabetes and lipid metabolism”. J. Adv. Med, 1993, 8:37-49.

[3] D. Wibowo. Fermentation Processes Biochemistry Teaching Materials (Bahan Ajaran Biokimia Proses Fermentasi). (PAU UGM Food and Nutrition, Yogyakarta, 1990).

[4] Amaria, Isnawati, Rini, and Tukiran. Saccharomyces cerevisiae biomass from fruit and vegetable waste as a source of vitamin B (Biomassa Saccharomyces Cerevisiae dari limbah buah dan sayur sebagai sumber vitamin B". The Papers Association of National Seminar on Food Technology, 2001, 138-150.

[5] Erna P. The Effect of Growing Media on Saccharomyces cerevisiae Protein Content in Making Single Cell Proteins (Pengaruh Media Tumbuh terhadap Kadar Protein Saccharomyces cerevisiae dalam Pembuatan Protein Sel Tunggal). (Sebelas Maret University, Surakarta, 2004).

[6] Food and Nutrition Board, Institute of Medicine. Dietary Reference Intakes for Vitamin A, Vitamin K, Arsenic, Boron, Chromium, Copper Iodine, Iron, Manganese, molybdenum, nickel, Silicon, Vanadium, and Zinc. (National Academy Press, Washington, DC, 2001).

[7] Eko Y, Pirim S. Producing Modified Carbon Paste Electrode for $\mathrm{Cr}$ (VI) Analyzing with Cyclic Stripping Voltammetry. State University of Surabaya: Indonesia, 2014. 